\title{
Factors Determining the Access to E-services of Public Institutions in Sri Lanka: A Case Study of Selected Divisional Secretariat Areas in Ampara District
}

\author{
M. A. M. Fowsar ${ }^{1} \&$ T. Fathima Sajeetha ${ }^{1}$ \\ ${ }^{1}$ Department of Political Science, Faculty of Arts and Culture, South Eastern University of Sri Lanka, Sri Lanka \\ Correspondence: T. Fathima Sajeetha, Department of Political Science, Faculty of Arts and Culture, South Eastern \\ University of Sri Lanka, Sri Lanka. E-mail: sajeetha@seu.ac.lk
}

Received: June 17, 2019

Accepted: July 2, 2020

Online Published: August 17, 2020

doi:10.5539/jpl.v13n3p80

URL: https://doi.org/10.5539/jpl.v13n3p80

\begin{abstract}
Enhancing e-service facilities to the citizens would make it easy for them to access various government and private services. It has currently become an essential aspect of the evolution of public administration. All governments, including those of third world countries, are now trying to improve their e-service delivery. E-service delivery is one of the fundamental mechanisms to enhance quality service delivery with transparency, effectiveness, and efficiency. Sri Lanka has made attempts to deliver e-services in multiple sectors, but many constraints have prevented all citizens from accessing those services. Against this backdrop, this study attempts to investigate the factors that influence the ability of citizens to access the various e-services in selected Divisional Secretariat areas of Ampara district, Sri Lanka. This study was conducted using both qualitative and quantitative research methods during the period from July 2018 to January 2019. The qualitative data were gathered from published books, research articles, and personal interviews, and the quantitative data were gathered through a structured questionnaire and statistical reports of government institutions. The collected data were analysed using both qualitative and quantitative techniques, and results are presented in text, tables and charts format. The findings of the study show that factors such as security, the availability of electronic device facilities, and low cost encouraged citizens to access these services often. Nevertheless, factors like difficulty in understanding e-services and concerns about its security have discouraged people from accessing e-services.
\end{abstract}

Keywords: e-services, public institutions, service delivery, using the device

\section{Introduction}

The principal responsibility of the state is to deliver goods and services to the citizens. Thus modern governments formulate various public policies and implement them to provide multiple services to citizens through public administration. Most of the governments have presently focused on developing strategies to provide certain services more effectively and conveniently by introducing e-government techniques, which enable citizens to access e-services. E-services indicate the services provided through digital means. As a powerful digital tool, the Internet is mostly used to provide e-service (Fowsar, 2013).

The electronic service is playing a pivotal role in both the public and private sectors. The private sector has already established e-service facilities for delivering services and gaining the satisfaction of customers. This has enabled the customers to cut expenditure and reduce the time spent on accessing the various services in private sectors. As a result, there is a trend that the people switch over to the private services from the public services. Over the past decades, the public sector has also introduced more e-services so that it could reach the citizens easily, and stay competitive with the private sector. Presently, Internet facilities are available in almost every populated locality, and these assist users to access all types of government information. It makes for an informed society that is able to interact with multiple actors. The introduction of mobile devices has enabled easy access to e-services for all categories of citizens.

Many scholars have conducted researches related to e-governance. Although most of those were limited to specific institutions, this study attempts to identify the factors that determine access to e-services by people from different social backgrounds. In Sri Lanka, the government made efforts to deliver e-services by introducing a National Computer Policy in 1983. Since then, the government has taken many actions to provide the e-services, but a range 
of factors determines people's inclination to access these types of services.

\section{Literature Review}

Governments, researchers, and policymakers across the world have paid much attention to increasing the availability of e-services over recent decades. E-services make for an informed society and improve the transparency and accountability of government services. There is no internationally standardised definition for eservices. As Scupola (as cited in Quaddus \& Woodside, 2015) described, e-services are facilities that are provided or consumed via the Internet. They are utilised in many fields such as politics, commerce, education, entertainment, etc. Through the provision of e-services, citizens can perform many activities effectively and efficiently.

Some scholars define e-services as the utilisation of ICT in different areas of public services (Dissanayake \& Dissanayake, 2013). As Kanchana and Samarakoon (2018) observed, e-governance is the primary alternative solution that has been established within society to curb corruption. Both technology-mediated and technologygenerated services are better known as electronic services or e-services (Cardoso \& Fromm, 2015). They are treated in the literature as new phenomena laid at the border between two main areas of study - marketing and ecommerce/e-business (Hoffman, 2003; Hofacker, Goldsmith, Bridges, \& Swilley, 2007). E-services are classified into many categories, as follows:

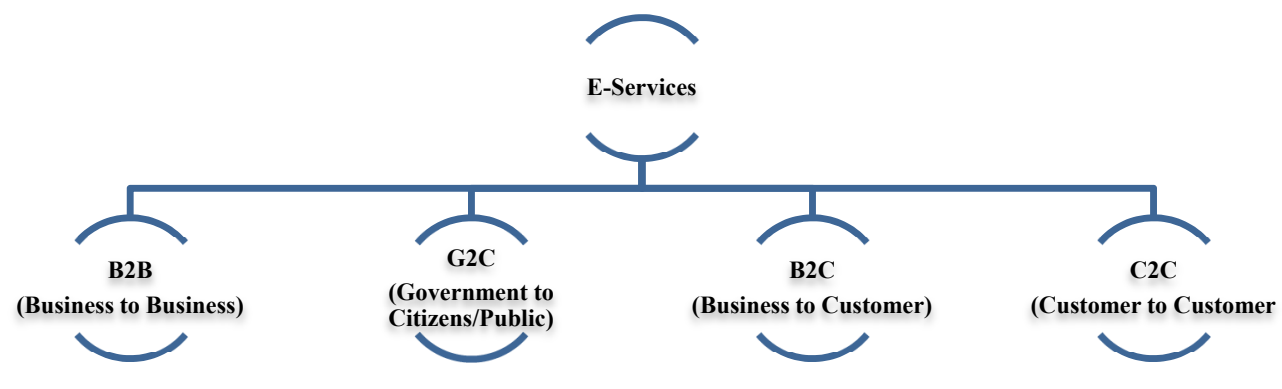

Figure 1. Types of e-services

(Source: Quaddus \& Woodside, 2015)

In Sri Lanka, the government recognised "E-Sri Lanka Development Project" in 2004 as the National Information Technology Action Plan. Accordingly, the Government Information Centre delivers all its services to citizens with a precise A-Z index (Dissanayake \& Dissanayake, 2013). Several studies have examined e-service practices and the factors that determine the access to e-services in Sri Lanka.

Sufna (2014) has identified four factors such as equity, responsiveness, openness and environmental sustainability. She further highlights that citizens have a positive outlook in the e-services provided by the Ministry of Public Administration, Sri Lanka. According to her study, the particular ministry is regularly updating the website, publishing the contents in Sinhala, Tamil, and English languages, following international web standards when posting information, developing facilities to conduct online transactions, and speeding up the transaction.

In another study, Sufna and Fernando (2016) argue that the majority of government officers had no idea about the public value of the website of the Ministry of Public Administration and Home Affairs (www.pubad.gov.lk). Only $20 \%$ of the officers have agreed that the particular website has public value. Also, Urumsah (2015) has identified several determinant factors of accessing e-services such as effort expectancy, social influence, facilitating conditions, privacy concerns, trustworthiness, outcome expectancy, motivation, intention to use, and some moderating factors (age, experience, and geographical area).

Sufna (2014) has cited that a previous study conducted by the United Nations (2012) had highlighted that 77.7\% of citizens were not aware of the e-government services in Sri Lanka. Further, Nawaz and Thelijjagoda (2015) have studied university academics' behavioural intention to use e-government services in Sri Lanka, and their research was primarily limited to the academics of the South Eastern University of Sri Lanka. From the above review of the literatures, it is evident that there is a significant gap in the study of accessing e-services in Sri Lanka. Hence, this study attempts to examine the factors that are determining the citizens' access to e-services in selected regions in the Ampara district of Sri Lanka. 


\section{Research Problem and Objectives}

In Sri Lanka, the government has launched e-services in various fields such as education, agriculture, healthcare, registration of persons, transport, etc. Despite that, most people do not have much awareness of e-services. Though people use the Internet for multiple purposes, they rarely use it for getting e-services from the government institutions. Therefore, this study attempts to identify the factors that contribute to the high access to e-services and factors that are responsible for the low access to e-services.

\section{Research Method}

\subsection{Data Collection}

This study is based on both qualitative and quantitative research methods. The qualitative data were gathered from published books, research articles, and personal interviews. The quantitative data were gathered from the structured questionnaire and statistical reports of government institutions. The primary data were collected through personal interviews and structured questionnaire during the field visits to obtain information on the access and usage of eservices. The statistical data of Ampara district were obtained from the Ampara District Secretariat. This research was conducted during the period from July 2018 to January 2019.

\subsection{Research Area}

The research area of this study comprises of selected Divisional Secretariat areas in Ampara district. Though Ampara district consists of 20 Divisional Secretariats, only six (6) of those areas were chosen to examine the research questions. They are Akkaraipattu, Sammanthurai, Ninthavur, Kalmunai Tamil division, Alayadivembu, and Karaitivu. These areas have two major ethnic communities, namely Tamils and Muslims, all of whom speak Tamil. Akkaraipattu, Sammanthurai, and Ninthavur have Muslims as the majority, whereas Alayadivembu, Kalmunai Tamil division (TD), and Karaitivu constitute Tamils as the majority. The ethnic demography of the research area is given in Table 1 .

Table 1 . The population of research area by ethnicity

\begin{tabular}{|c|c|c|c|c|c|c|}
\hline \multirow{2}{*}{ S.No. } & \multirow{2}{*}{$\begin{array}{c}\text { Divisional } \\
\text { Secretariats }\end{array}$} & \multicolumn{4}{|c|}{ Ethnicity } & \multirow{2}{*}{ Total } \\
\hline & & Sinhalese & Tamils & Muslims & Others & \\
\hline 01 & Alayadivembu & 374 & 24,216 & 24 & 1,288 & 25,902 \\
\hline 02 & Ninthavur & 0 & 927 & 30,679 & 0 & 31,606 \\
\hline 03 & Karaitivu & 0 & 10,995 & 7,770 & 120 & 18,885 \\
\hline 04 & Akkaraipattu & 77 & 126 & 43,634 & 0 & 43,837 \\
\hline 05 & Sammanthurai & 48 & 9,208 & 61,236 & 1,003 & 71,495 \\
\hline 06 & Kalmunai (TD) & 170 & 31,269 & 3,070 & 1,017 & 35,526 \\
\hline & Total & 669 & 76,741 & 146,413 & 3,428 & 227,251 \\
\hline
\end{tabular}

(Source: Ampara District Secretariat, 2017)

\subsection{Sample Selection}

Three interviewees were selected by purposive sampling method from each Divisional Secretariat area. Therefore, a total of 18 interviews were carried out to get more information and explanation on each factor. The questionnaires were distributed among the six Divisional Secretariat areas. Random sample selection method was used for the structured questionnaire survey. One hundred fifty-one questionnaires were distributed according to the population of selected areas. The first section of the questionnaire was about the respondents' demographic details, and the second part dealt with the research objectives. Table 2 shows how the questionnaires were distributed in the research area with different ethnic compositions. 
Table 2. Sample selection for questionnaire distribution

\begin{tabular}{|c|c|c|c|c|c|c|c|c|c|c|c|}
\hline \multirow{2}{*}{ No. } & \multirow{2}{*}{$\begin{array}{c}\text { Divisional } \\
\text { Secretariats }\end{array}$} & \multicolumn{8}{|c|}{ Ethnicity } & \multirow{2}{*}{ Total } & \multirow{2}{*}{$\begin{array}{r}\text { Total } \\
\text { Sample }\end{array}$} \\
\hline & & Sinhalese & Sample & Tamils & Sample & Muslims & Sample & Others & Sample & & \\
\hline 01 & Alayadivembu & 374 & $\mathbf{0}$ & 24,216 & 16 & 24 & 0 & 1,288 & 1 & 25,902 & 17 \\
\hline 02 & Ninthavur & 0 & $\mathbf{0}$ & 927 & 1 & 30,679 & 20 & 0 & 0 & 31,606 & 21 \\
\hline 03 & Karaitivu & 0 & $\mathbf{0}$ & 10,995 & 7 & 7,770 & 5 & 120 & 0 & 18,885 & 12 \\
\hline 04 & Akkaraipattu & 77 & $\mathbf{0}$ & 126 & 0 & 43,634 & 29 & 0 & 0 & 43,837 & 29 \\
\hline 05 & Sammanthurai & 48 & $\mathbf{0}$ & 9,208 & 6 & 61,236 & 41 & 1,003 & 1 & 71,495 & 48 \\
\hline 06 & Kalmunai (TD) & 170 & $\mathbf{0}$ & 31,269 & 21 & 3,070 & 2 & 1,017 & 1 & 35,526 & 24 \\
\hline \multicolumn{10}{|c|}{ Total } & 227,251 & 151 \\
\hline
\end{tabular}

\subsection{Data Analysis}

Data collected from the interviews and literature review were analysed according to the descriptive method while the completed questionnaires were analysed using SPSS (Statistical Package for the Social Sciences). The selected dependent and independent variables were used for the analysis. Using electronic devices for accessing e-services was taken as the dependent variable. Socio-demographic related factors were considered as independent variables to examine their influence on accessing e-services when testing specific hypotheses. The table - 04 illustrates sociodemographic variables. The descriptive-frequency method was used to analyse them. Factors that determine the access to e-services were analysed using the descriptive-crosstabs - Pearson Chi-Square method. The following hypotheses were proposed and tested.

Null Hypothesis: There is no relationship between independent and dependent variables.

Alternative Hypothesis: There is a relationship between independent and dependent variables.

\section{Results and Discussions}

\subsection{Knowledge of Electronic Services}

This study estimated the level of people's knowledge of e-services by DS division and gender, learning methods, access of e-services from public institutions and the reasons behind access of e-services as well as the types of devices used to access to e-services.

Table 3. Knowledge of electronic services

\begin{tabular}{|c|c|c|c|c|c|c|c|c|c|c|}
\hline & & & \multicolumn{6}{|c|}{ DS Division } & \multicolumn{2}{|c|}{ Gender } \\
\hline & & & $\begin{array}{c}\text { Akkaraip } \\
\text { attu }\end{array}$ & $\begin{array}{c}\text { Sammanth } \\
\text { urai }\end{array}$ & Ninthavur & $\begin{array}{c}\text { Alaydivemb } \\
\text { u }\end{array}$ & Karaithivu & $\begin{array}{c}\text { Kalmunai } \\
\text { TD }\end{array}$ & Male & Female \\
\hline \multirow{3}{*}{ 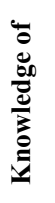 } & \multirow{3}{*}{ 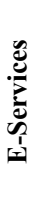 } & Yes & $19.5 \%$ & $32.2 \%$ & $15.3 \%$ & $11.9 \%$ & $8.5 \%$ & $12.7 \%$ & 85.3 & 70.7 \\
\hline & & No & $25.0 \%$ & $16.7 \%$ & $0.0 \%$ & $25.0 \%$ & $0.0 \%$ & $33.3 \%$ & 5.3 & 10.7 \\
\hline & & $\begin{array}{c}\text { Not } \\
\text { Much }\end{array}$ & $14.3 \%$ & $38.1 \%$ & $14.3 \%$ & $0.0 \%$ & $9.5 \%$ & $23.8 \%$ & 9.2 & 18.7 \\
\hline
\end{tabular}

According to the above table, the respondents from Akkaraipattu and Alaiyadivembu were hardly aware of the eservices available in their area (25\%). At the same time, all the respondents from Karaithivu and Ninthavur seemed to know about the e-services. This study also found that a high percentage of respondents from Sammanthurai were aware of the e-services (32.2\%). In the case of people from the Kalmunai Tamil DS division, the majority did not know about the availability of e-services (33.33\%).

Males comparatively know about e-services than females. Only $70.7 \%$ of females knew about the e-services, while $10.7 \%$ of female respondents seemed to be unaware of e-services. Respondents came to know about the e-services via multiple means such as friends, mass media, the Internet, information of public institutions, and other ways. According to their responses, mass media, Internet, and friends were the most effective at instilling awareness about the e-services. Further, $7.91 \%$ of the respondents came to know about it from the information of public institutions. Figure 2 indicates the learning methods of e-services. 


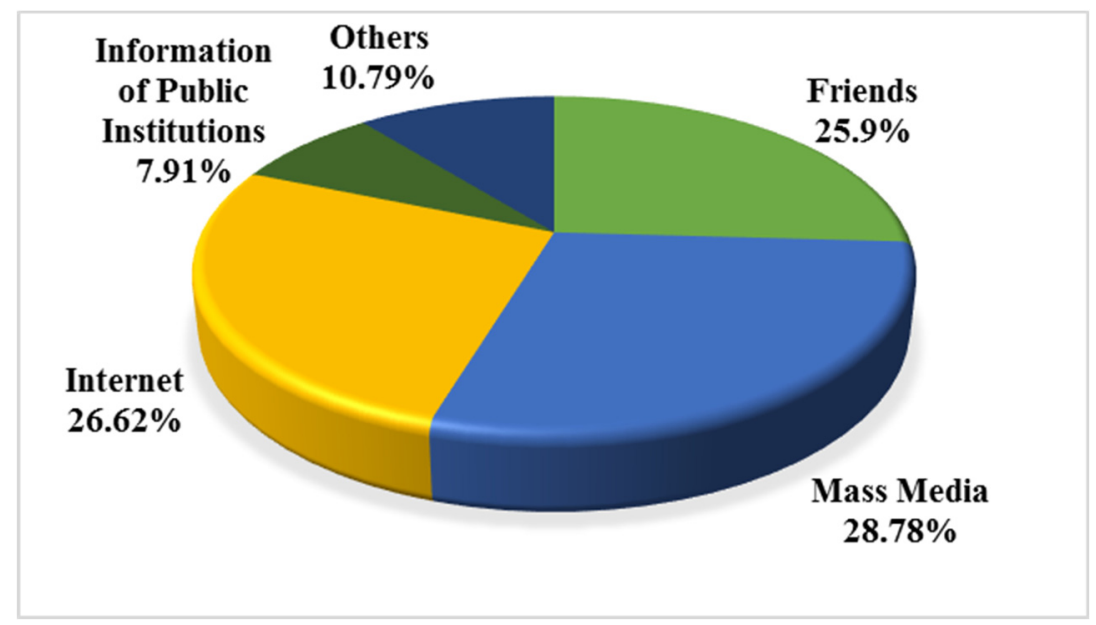

Figure 2. Learning methods regarding e-services

People in the research area have accessed the e-services in various public institutions such as banks, Divisional Secretariats, educational institutions including schools, government hospitals, police stations, local government offices, and other government institutions. According to the analysed data, most of the respondents have received the e-services from banks, and a few people got e-services from the police. Figure 3 clearly describes the public institutions where people access to e-services.

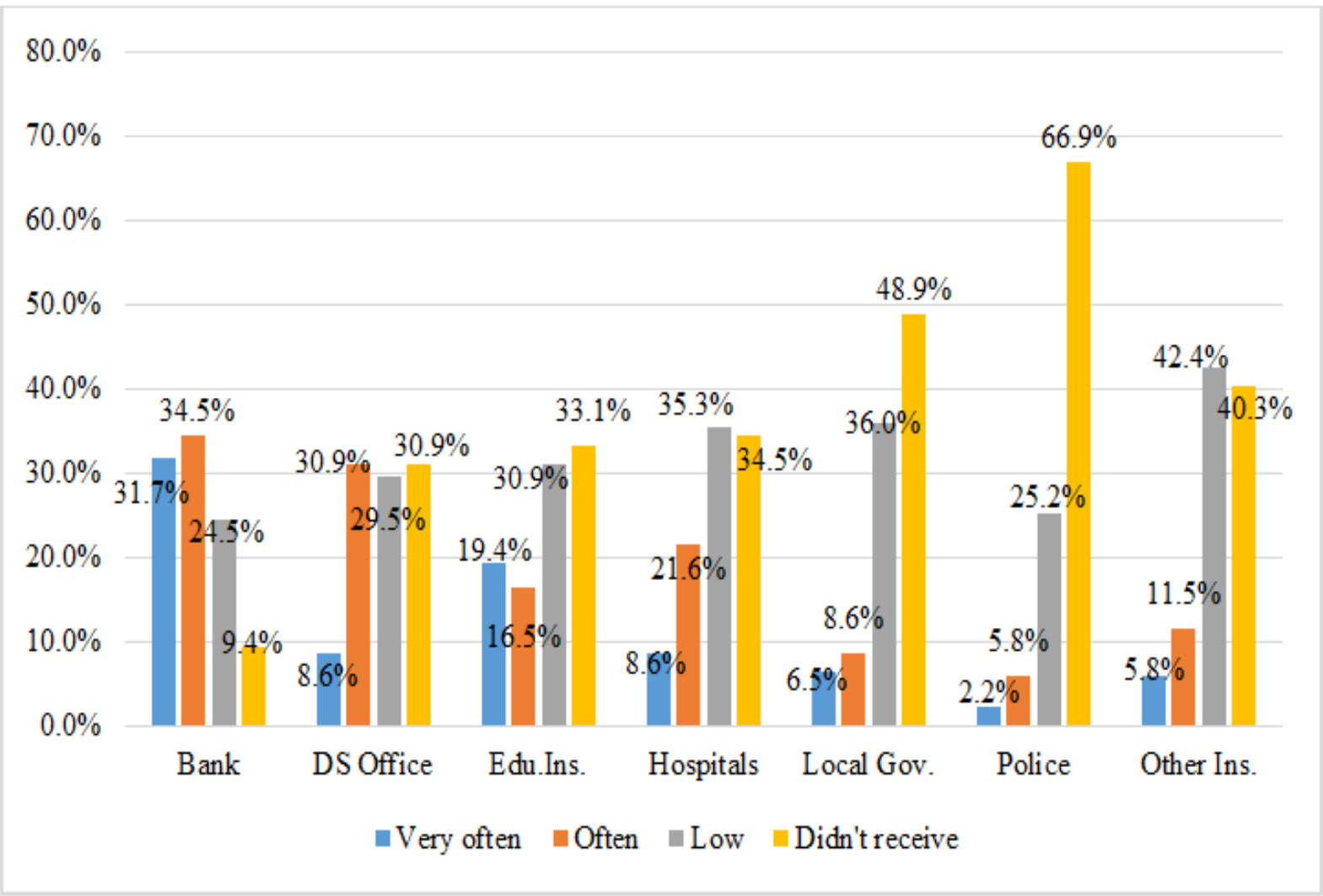

Figure 3. Access of e-services in public institutions

In the questionnaire survey, the respondents were asked why and how often e-services are accessed? Respondents gave their answers as very often, often, sometimes, and never (see Figure 4). 


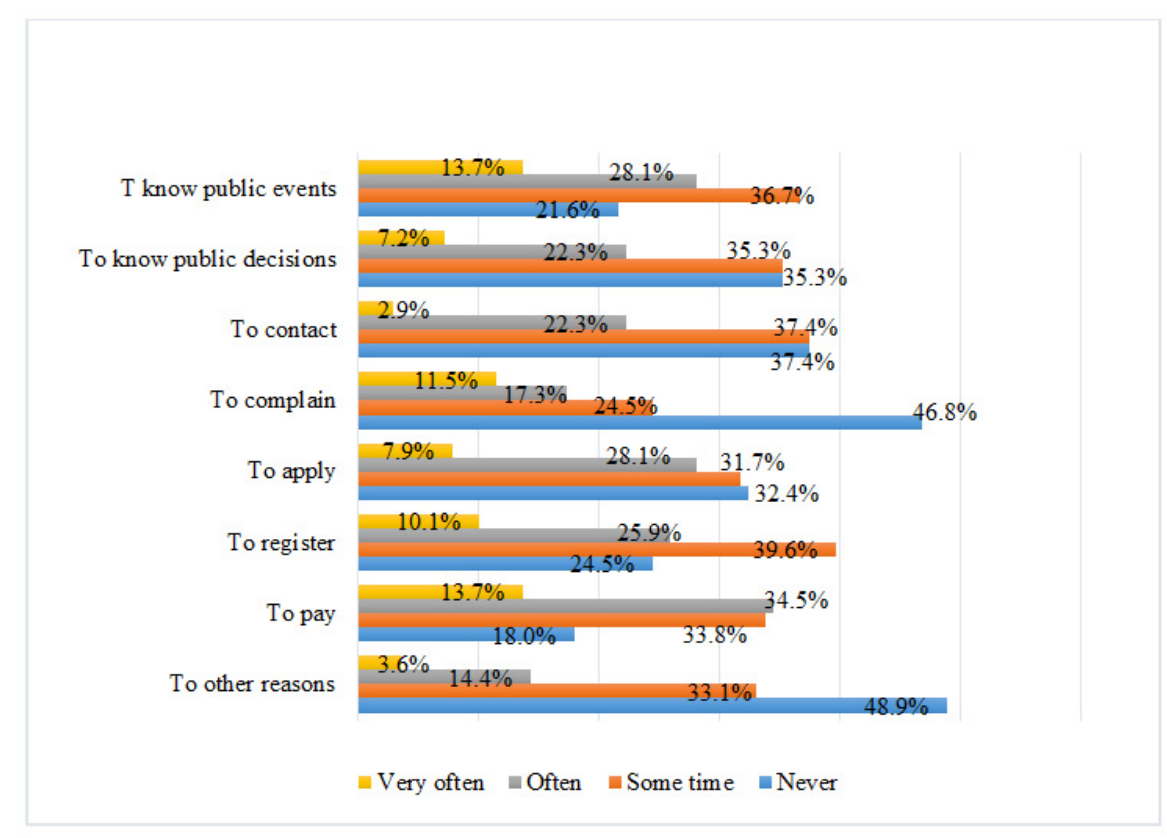

Figure 4. Reasons for accessing e-services

According to figure $4,13.7 \%$ of respondents have accessed to e-services very often, both to learn about public events and to make payments. Majority of the respondents have accessed to e-services occasionally and for various purposes that are shown in the chart; a high number of these respondents have accessed to e-services to pay bills, etc. and to learn about events. Many respondents $(48.9 \%)$ never access the e-services for any other reasons. Some of the respondents $(22.3 \%)$ have obtained e-services only to learn about public decisions and to contact public officials.

In addition to all that, people have accessed to the e-services frequently on their smartphone, computer, laptop, and tab. The tab is the device that has the lowest usage $(2.16 \%)$ for accessing e-services. The smartphone is one of the cheapest devices, and most people have a good knowledge of how to use it. Therefore most of them have used the smartphone to access e-services. Figure 5 shows the usage of various devices for accessing the e-services.

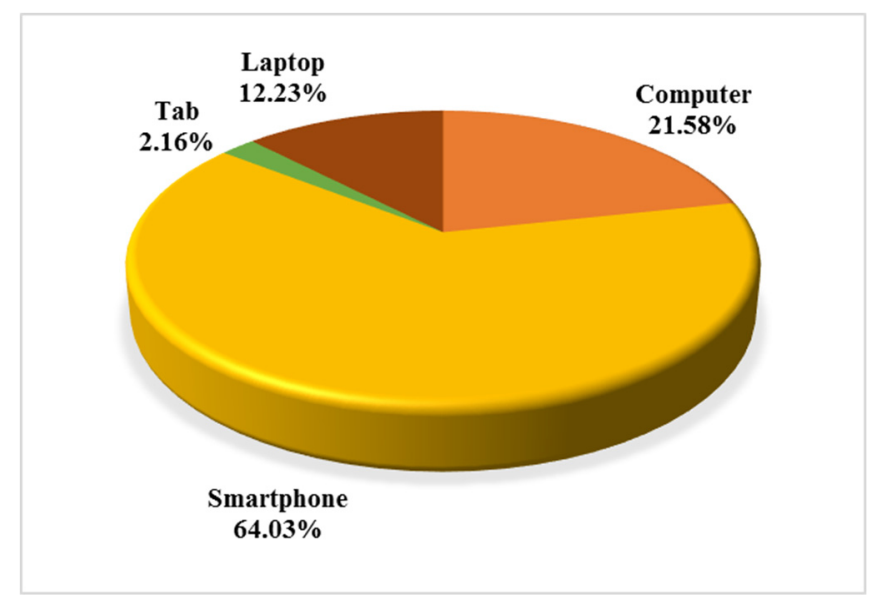

Figure 5. Use of different devices to access the e-services

\subsection{Influence of Socio-demographic Variables}

This research examined some socio-demographic variables such as age, gender, ethnicity, education, and occupation that are likely to have some influence on accessing e-services. These variables were displayed in the below table 4 . 
Table 4. Influence of socio-demographic variables

\begin{tabular}{|c|c|c|c|c|c|}
\hline \multicolumn{2}{|c|}{ Socio-demographic variables } & \multirow{2}{*}{$\begin{array}{r}\text { Computer } \\
30.0 \%\end{array}$} & \multirow{2}{*}{$\begin{array}{r}\text { Smartphone } \\
29.2 \%\end{array}$} & \multirow{2}{*}{$\frac{\text { Tab }}{66.7 \%}$} & \multirow{2}{*}{$\begin{array}{r}\text { Laptop } \\
23.5 \%\end{array}$} \\
\hline \multirow{5}{*}{ Age } & $18-25$ & & & & \\
\hline & $26-35$ & $20.0 \%$ & $19.1 \%$ & $0.0 \%$ & $5.9 \%$ \\
\hline & $36-45$ & $13.3 \%$ & $19.1 \%$ & $0.0 \%$ & $29.4 \%$ \\
\hline & $46-55$ & $26.7 \%$ & $24.7 \%$ & $33.3 \%$ & $17.6 \%$ \\
\hline & 56-Above & $10.0 \%$ & $7.9 \%$ & $0.0 \%$ & $23.5 \%$ \\
\hline \multirow{2}{*}{ Gender } & Male & $46.7 \%$ & $55.1 \%$ & $0.0 \%$ & $52.9 \%$ \\
\hline & Female & $53.3 \%$ & $44.9 \%$ & $100.0 \%$ & $47.1 \%$ \\
\hline \multirow{4}{*}{ Ethnicity } & Sinhalese & $0.0 \%$ & $0.0 \%$ & $0.0 \%$ & $0.0 \%$ \\
\hline & Tamils & $36.7 \%$ & $37.1 \%$ & $0.0 \%$ & $17.6 \%$ \\
\hline & Muslim & $60.0 \%$ & $60.7 \%$ & $100.0 \%$ & $82.4 \%$ \\
\hline & Others & $3.3 \%$ & $2.2 \%$ & $0.0 \%$ & $0.0 \%$ \\
\hline \multirow{7}{*}{ Education } & No Study & $0.0 \%$ & $1.1 \%$ & $0.0 \%$ & $0.0 \%$ \\
\hline & Primary & $3.3 \%$ & $2.2 \%$ & $0.0 \%$ & $11.8 \%$ \\
\hline & $6-8$ & $20.0 \%$ & $27.0 \%$ & $0.0 \%$ & $35.3 \%$ \\
\hline & $9-11$ & $0.0 \%$ & $1.1 \%$ & $0.0 \%$ & $0.0 \%$ \\
\hline & $\mathrm{A} / \mathrm{L}$ & $10.0 \%$ & $6.7 \%$ & $33.3 \%$ & $11.8 \%$ \\
\hline & Degree & $33.3 \%$ & $41.6 \%$ & $66.7 \%$ & $35.3 \%$ \\
\hline & Post Graduate & $33.3 \%$ & $20.2 \%$ & $0.0 \%$ & $5.9 \%$ \\
\hline \multirow{7}{*}{ Occupation } & Government & $10.0 \%$ & $21.3 \%$ & $33.3 \%$ & $23.5 \%$ \\
\hline & Self-Employment & $26.7 \%$ & $28.1 \%$ & $0.0 \%$ & $23.5 \%$ \\
\hline & Retired & $6.7 \%$ & $5.6 \%$ & $0.0 \%$ & $5.9 \%$ \\
\hline & Private & $10.0 \%$ & $15.7 \%$ & $0.0 \%$ & $17.6 \%$ \\
\hline & Student & $36.7 \%$ & $24.7 \%$ & $66.7 \%$ & $17.6 \%$ \\
\hline & Unemployed & $10.0 \%$ & $2.2 \%$ & $0.0 \%$ & $11.8 \%$ \\
\hline & Others & $0.0 \%$ & $2.2 \%$ & $0.0 \%$ & $0.0 \%$ \\
\hline
\end{tabular}

1) Age and its Influence on Usage of E-services

Age determines the activities of men as it can influence what they can do and cannot do. In this context, the age is considered as one of the independent variables. Therefore, its influence in accessing e-services was tested. According to the findings, respondents in both the 18-25 and 46-55 age groups have frequently accessed e-services on the smartphone. In addition to that, all age groups have obtained e-services on the computer.

2) Gender and Access of E-services

This research focuses on the use of devices to access e-services by gender, as this is one of the prominent demographic features. As seen in the table - 04, females occupy the dominant place in using the computer (53.3\%), but males are heavy users of smartphones (55.1\%). Those who use tabs for accessing e-services are exclusively female $(100 \%)$.

\section{3) Ethnicity and Access of E-services}

Ethnicity is one of the key demographic factors that differentiate people into groups. It plays a vital role in various social activities, which are based on culture, social setup, traditions, etc. This study attempted to estimate the usage of e-services by ethnicity. According to the table - 04, both Tamils and Muslims have access to e-services, but Muslims have tended to access them by using all types of devices discussed here. As well, respondents who were Tamils have not generally used the tab to access to e-services. Computers and smartphones were used to about the same extent by each ethnicity. 


\section{4) Education and Access of E-services}

Education is the next demographic feature used in this study. According to the above table, an equal percentage of respondents (35.3\%) from both groups, that is, those who have a degree and those who have passed Grades 6-8, have access to e-services by using smartphones. Further, respondents of all age categories have used the computer for accessing e-services.

\section{5) Occupation and Access of E-services}

Respondents who were working in the government sector have accessed to e-services more frequently than those working in the private sector. Just like the students, they have used to access the e-services using a computer (36. $7 \%$ ) or a tab (66. 7\%). The smartphones were used by people engaged in all categories of occupation. Hence, students and government employees have used all devices to access e-services. However, respondents who were self-employed, working in the private sector, unemployed people, and some others did not use tab.

\subsection{Influence of Various Factors in Accessing E-services}

Table 5 shows whether the proposed hypotheses were accepted or rejected by analysing the data in SPSS. In this analysis, using a device for accessing e-services has been taken as a dependent variable. In Chi-Square testing, Pearson Chi-Square should be equal or lower than 0.05 to accept a significant relationship between the dependent and independent variables (i.e. alternative hypothesis is accepted). Otherwise, the alternative hypothesis is rejected.

Table 5. Summary of hypothesis testing

\begin{tabular}{llcc}
\hline S.No & Independent variables & $\begin{array}{c}\text { Pearson Chi- } \\
\text { Square }\end{array}$ & $\begin{array}{c}\text { Hypothesis - Accepted/ } \\
\text { Rejected }\end{array}$ \\
\hline \multicolumn{1}{c}{ Factors responsible for the high access of e-services } \\
\hline $\mathbf{1}$ & Confidence & 0.089 & Rejected \\
$\mathbf{2}$ & Security & 0.003 & Accepted \\
$\mathbf{3}$ & Ease of use & 0.606 & Rejected \\
$\mathbf{4}$ & Internet knowledge & 0.205 & Rejected \\
$\mathbf{5}$ & Electronic device facilities & 0.012 & Accepted \\
$\mathbf{6}$ & Low cost & 0.050 & Accepted \\
\hline & \multicolumn{1}{c}{ Factors responsible for the low access of e-services } & \\
\hline $\mathbf{1}$ & Lack of electronic devices with Internet & 0.235 & Rejected \\
$\mathbf{2}$ & Low knowledge of Internet & 0.740 & Rejected \\
$\mathbf{3}$ & Uncertainty & 0.540 & Rejected \\
$\mathbf{4}$ & Hard to understand & 0.013 & Accepted \\
$\mathbf{5}$ & Worried about security & 0.041 & Accepted \\
$\mathbf{6}$ & No new updates & 0.666 & Rejected \\
\hline
\end{tabular}

This study tested 12 factors as independent variables with a null and alternative hypothesis. But only five factors had a significant influence on the access of e-services. According to that, security, electronic devices with Internet connectivity, low cost, hard to understand, and worried about security are the factors that influence and determine the access.

As far as factors that determine the high access of e-services are concerned, the following have a significant relationship with the dependent variable. Pearson Chi-Square of security is lower than 0.05 . Thus, the alternative hypothesis is accepted, and the null hypothesis is rejected. Security is one of the independent variables that determine people's access. People believe that e-services will be neutral and secure their rights to service delivery. They think that accessing e-services will be helpful to get the services without any clashes that are likely to arise during human to human interactions. If their money, documents, or other information are accessed directly by themselves, there will be less chance of errors. And their details get updated on time. Also, their personal information is not likely to be misused. 
As well as electronic device facilities, there is also the Pearson Chi-Square value, which is less than 0.05 . Thus, the alternative hypothesis is accepted, and the null hypothesis is rejected. Generally, most people now have electronic devices with Internet connectivity. However, few people use devices without internet connectivity. The Internet connectivity plays a significant role in accessing e-services. Therefore, electronic devices with Internet facilities are an essential need for citizens in the contemporary global setting. It makes it easy for them to become aware of happenings instantly. It provides people with options and alternatives to pursue their interests. People who have electronic devices with these facilities can get services from public institutions both directly and indirectly.

The third factor that is significant and has the same value of 0.05 Pearson Chi-Square is low cost. Thus, the alternative hypothesis is accepted. It is found that when people have to attend public institutions for getting any services physically, it can result in unnecessary expenses. But e-services help to get things done at a low cost. When they access to e-services, they do not have to incur travelling expenses, inquiry and application fees, etc. Accessing e-services is cheaper than conventional service delivery as it helps to avoid incidental expenditures.

According to the above discussion, only three factors are found to have a positive impact on high access to eservices. Other three factors, such as confidence, ease of use and Internet knowledge have a Pearson Chi-Square value of more than 0.05 . Still, they do not have a significant relationship with the dependent variable. Because of that, the null hypothesis is accepted, and the alternative hypothesis is rejected.

Further, this study identified the factors that are responsible for low access to e-services. Six factors were tested, but only two factors had significant Pearson Chi-Square value. Accordingly, hard to understand, and worried about security had significant relationships and less than 0.05 Pearson Chi-Square value. Thus, the alternative hypothesis is accepted, and the null hypothesis is rejected for these two factors.

Hence, accessing e-services can be very difficult for some people. If most of the e-services involve interacting in English, it will be very hard for the Tamil speaking people who are not conversant in English. Even if certain eservices can be processed in Tamil, some people do not understand the special terms used. As many options may be available, people often feel confused and uncomfortable. Because of that, it takes more time to access some eservices.

Another problem is that people are often worried about the information security issues involved in accessing eservices. They are afraid of hackers because nowadays, cyber-crimes have been increasing steadily. Many persons with specialised knowledge have the ability to access the personal details of others through online. Sometimes people are misled and cheated by false information. They feel threatened. Therefore, people who use smartphones are worried that if they lose their phones, their details will be misused. This is one of the critical factors restricting access to e-services.

The lack of electronic devices with the Internet connection, poor knowledge of Internet, uncertainty, and lack of updates were the factors that did not show a significant relationship in the Pearson Chi-Square test (their values were more than 0.05). Thus, alternative hypotheses is rejected.

\section{Conclusion}

This study attempted to identify the factors that determine the access of e-services in selected Divisional Secretariat areas in Ampara district using both qualitative and quantitative methods. Using a device for accessing e-services was taken as the dependent variable. Five demographic features taken as the independent variables were analysed using the descriptive - frequency method. Twelve factors selected as independent variables were tested using the Pearson Chi-Square method. It was found in this test that only five factors showed a significant relationship with the dependent variable. Of these, two factors were identified as contributing to the low access to e-services. The factors are 'hard to understand' and 'worried about security'.

To increase access to e-services by reducing the effects of these two factors, people should become more aware of technology and e-services. Also, service providers should ensure the privacy of their clients' documents and personal details. Further, public institutions should increase access to e-services by providing more publicity for their services. It emphasises transparency, effectiveness, and efficiency. This study will prove useful for future researches that attempt to find out more about the factors that influence on the access to e-services.

\section{Suggestions for Further Researches}

This study identified the factors that determine the access to e-services in selected Divisional Secretariat areas in Ampara district, Sri Lanka. However, this study did not include Sinhala speaking people. It is also important to consider awareness among Sinhala speaking people in accessing e-services. The study further suggests that additional issues relating to e-service delivery mechanisms should be addressed in future researches. 


\section{References}

Ampara District Secretariat. (2017). Statistical information handbook of Ampara district. Ampara: Ampara District Secretariat.

Cardoso, J., \& Fromm, H. (2015). Electronic services. Retrieved from https://www.springer.com/cda/content/document/cda_downloaddocument/9783319231945c1.pdf?SGWID=0-0-45-1544442-p177650914

Dissanayake, S., \& Dissanayake, L. (2013). Development of e-governance in Sri Lanka. In E. F. Halpin, D. Griffin, C. Rankin, L. Dissanayake \& N. Mahtab (Eds.), Digital public administration and e-government in developing nations: Policy and practice. USA: Information Science Reference.

Fowsar, M.A.M. (2013). E-governance in Sri Lanka: Opportunities and challenges. Global Journal of Arts and Management, 3(3), 135-139.

Hofacker C.F., Goldsmith R.E., Bridges E., \& Swilley E. (2007). E-Services: A Synthesis and Research Agenda. In: E-Services. DUV. https://doi.org/10.1007/978-3-8350-9614-1_3

Hoffman, K. D. (2003). Marketing + MIS = Eservice. Communications of the ACM, 46(6), 53-55. https://doi.org/10.1145/777313.777340

Kanchana, D. G., \& Samarakoon, A. K. (2018). The role of e-governance in curbing public sector corruption (A theoretical overview). OUSL Journal, 13(1), 5-27. https://doi.org/10.4038/ouslj.v13i1.7404

Nawas, S. S., \& Thelijjagoda, S. (2015). University academics' behavioural intention to use e-government services in Sri Lanka. Information and Knowledge Management, 5(6), 51-58. Retrieved from http://ir.lib.seu.ac.lk/bitstream/handle/123456789/1282/UK\%20PAPER\%20SANA\%20SAMANTHA\%20II $\% 207$.pdf? sequence $=3 \&$ isAllowed $=\mathrm{y}$

Quaddus, M., \& Woodside, A. G. (Eds.). (2015). E-services adoption: Process by firms in developing nations. UK: Emerald Group Publishing Limited. https://doi.org/10.1108/S1069-096420150000023010

Sufna, M. N. N. (2014). Critical factors affecting the user value of e-government in Sri Lanka: An empirical study on Ministry of Public Administration and Home Affairs (Unpublished Master's Thesis). Sri Lanka: University of Sri Jayewardenepura. https://doi.org/10.2139/ssrn.2706974

Sufna, N., \& Fernando, R. L. (2016). Public value of e-government: The case of Ministry of Public Administration and Home Affairs in Sri Lanka. In I. S. Sodhi (Ed.), Trends, prospects, and challenges in Asian e-governance. Information Science Reference. https://doi.org/10.4018/978-1-4666-9536-8.ch008

Urumsah, D. (2015). Factors influencing consumers to use e-services in Indonesian airline companies. In M. Quaddus, \& A. G. Woodside (Eds.), E-services adoption: Process by firms in developing nations. UK: Emerald Group Publishing Limited. https://doi.org/10.1108/S1069-09642015000023B002

\section{Copyrights}

Copyright for this article is retained by the author(s), with first publication rights granted to the journal.

This is an open-access article distributed under the terms and conditions of the Creative Commons Attribution license (http://creativecommons.org/licenses/by/4.0/). 